\title{
Leptospirosis and its spatial and temporal relations with natural disasters in six municipalities of Santa Catarina State, Brazil from 2000 to 2016
}

\author{
Ana Elisa Pereira Silva, Francisco Chiaravalloti Neto, Gleice Margarete de Souza Conceição \\ School of Public Health, University of São Paulo, São Paulo, Brazil
}

\begin{abstract}
The aim of this study was to identify clusters of relatively higher risk for leptospirosis occurrence related to flooding and landslides between 2000 and 2016 in six municipalities in the state of Santa Catarina, Brazil. A spatiotemporal study was carried out to evaluate the potential coincidence between the occurrence of leptospirosis clusters and natural disasters. The cases were geocoded with the geographic coordinates of patients' home addresses, and the analysis performed using SaTScan software. Temporal and spatiotemporal analysis showed significant clusters of leptospirosis, particularly in men 15 to 69 years of age, in all municipalities in 2008, and one in 2011, when natural disasters occurred after heavy rainfall. In these clusters, most of the infected individuals lived in urban areas and in areas at risk for natural disasters. The interaction between time (of disaster occurrence) and space (where natural disasters struck) were the determining factors affecting leptospirosis cluster formation.
\end{abstract}

\footnotetext{
Correspondence: Ana Elisa Pereira Silva, School of Public Health, University of São Paulo, Avenida Doutor Arnaldo 715, São Paulo, 01246904 SP, Brazil.

Tel.: +55.12.98156-3919

E-mail: anaepsilva@hotmail.com

Key words: Leptospira; risk areas; geoprocessing; SaTScan; Brazil.

Funding: This research study was approved by the University of São Paulo School of Public Health Research Ethics Committee in accordance with Resolution CNS 196/96 (protocol number CAAE 69803417.2.0000.5421; July 6, 2017). This work was supported by the National Council for Scientific and Technological Development (Conselho Nacional de Desenvolvimento Científico e Tecnológico, CNPq) [PhD scholarship].
}

Conflict of interests: The authors declare no potential conflict of interests.

Received for publication: 6 June 2020.

Accepted for publication: 29 September 2020.

(C) Copyright: the Author(s), 2020

Licensee PAGEPress, Italy

Geospatial Health 2020; 15:903

doi:10.4081/gh.2020.903

This article is distributed under the terms of the Creative Commons Attribution Noncommercial License (CC BY-NC 4.0) which permits any noncommercial use, distribution, and reproduction in any medium, provided the original author(s) and source are credited.

\section{Introduction}

Leptospirosis is an infectious disease caused by Lepstospira bacteria. The disease has an abrupt onset and can present in a range of forms from asymptomatic to severe and fatal. According to the Brazilian Ministry of Health $(\mathrm{MoH})$, it is not uncommon in Brazil (MoH, 2010). In humans, the infection is the result of direct or indirect contact with the urine of infected animals, especially rodents allowing bacteria to penetrate the body through the mucosa, damaged skin or even intact skin if immersed for long periods in contaminated water. $(\mathrm{MoH}, 2017)$. In general, the number of cases peaks during the rainy season and may reach epidemic proportions in the event of flooding because this promotes rodent mobility, so that they also can invade cities (WHO, 2019).

This bacterial disease is severe and occurs worldwide, although it is more prevalent in tropical and subtropical regions, with high incidence rates in urban and economically disadvantaged areas (WHO, 2009; Romero-Vivas and Falconar, 2016). It has become socially and economically important due to its high incidence and high cost due to hospitalizations, missed working days and adding to the burden of Disability-Adjusted Life Years (DALYs) with mortality rates reaching as high as $40 \%$ (Souza et al., 2011; Traxler et al., 2014; MoH, 2017).

Sudden or gradual flooding and landslides are natural disasters that may favour an increase in the incidence of diseases depending on vectors, reservoirs and hosts. Leptospirosis belongs to this group as, according to Freitas et al. (2014), the percentage of individuals exposed, the morbidity rate and the mortality rate due to leptospirosis are all more strongly associated with hydrological events than with other natural disasters. In Brazil, leptospirosis has occurred in all states and is therefore considered endemic. In the last 10 years, the country has had over 3,600 confirmed cases and approximately 375 deaths per year. The incidence is higher in the Southeast and South (MS, 2017). According to Department of Informatics of Brazilian Health System (Departamento de Informática do SUS, DATASUS), Santa Catarina (SC) was the state with the third highest incidence of leptospirosis in the country between 2001 and 2015, and it had also the highest incidence and the 2nd highest mortality rate of all the states in 2008 (DATASUS, 2019).

Cluster detection would be a way to find the hotspots of leptospirosis transmission. A method of identifying significant clusters of disease cases, including leptospirosis, in Brazil and worldwide has been employed in scientific studies (Coleman et al., 2009; Kugeler et al., 2015; Sumanta et al., 2015; Cardim et al., 2016; Melchior and Chiaravalloti Neto, 2016; Sulistyawati et al., 2016; Pellini et al., 2017; Bermudi et al., 2018; Farinelli et al., 2018; Gutiérrez and Martínez-Vega, 2018; Pinto et al., 2018; Deshmukh et al., 2019). It is a scanning technique developed and implemented with SaTScan that allows the evaluation of whether cases of a disease are randomly distributed in space, time and 
space-time. From 1990 to 2010, south-eastern and southern Brazil experienced a relatively high number of hydrological phenomena. According to Brazil's natural disaster records, sudden and gradual floods occurred throughout all years of this period in the South, with the most frequent sudden floods occurring between September and February. From 2003 to 2012, the largest number of emergency and public calamity decrees for this kind of events recorded in Brazil occurred in these regions. SC had the largest number of both decrees (emergency and public calamity by hydrological event) in the country because, among the 12 most affected municipalities in the country, nine were in this state (Organização Pan-Americana da Saúde, OPAS, 2014). Since these regions also have the highest concentrations of leptospirosis cases, there might be an association between leptospirosis transmission and natural disasters in this part of the country.

To study this an investigation was performed to describe the occurrence of leptospirosis in space, time and space-time between 2000 and 2016 in the six municipalities of SC that had the highest incidence of the disease in that period. It was intended to identify clusters of greatest risk for the occurrence of the disease in those municipalities, both from spatial and temporal points of view and to evaluate whether these clusters coincided with areas at risk of experiencing natural disasters. The more risk factors that are identified and understood, the more successful the application of interventions at individual and community level and prevention of the disease will be (WHO, 2010).

\section{Materials and methods}

\section{Study design}

A descriptive and ecological study was performed in which the units of analysis were, depending on the scale of the study, the state of SC, the municipality and the Census tract.

\section{Study area for the identification of areas at risk for natural disasters}

According to the Brazilian Institute of Geography and Statistics (Instituto Brasileiro de Geografia e Estatística, IBGE), the state of SC is divided into 295 municipalities comprising a total area of $95,730,921 \mathrm{~km}^{2}$ (IBGE, 2018). For this study, we selected the six municipalities with population greater than 50,000 inhabitants and with the highest incidence of leptospirosis in the period of interest. They were: Camboriú, Navegantes, Itajaí, Blumenau, Gaspar and Jaraguá do Sul. Municipalities with smaller population were not selected because in those areas, the incidence coefficients usually have large fluctuations in space-time due to small variations in the number of cases of the disease, leading to spurious associations and conclusions. Figure 1 shows the geographical location of SC in southern Brazil and its municipalities with these six municipalities highlighted.

The state is affected by a great diversity of natural adverse events: droughts, flooding, flash floods, hail, landslides, wind-

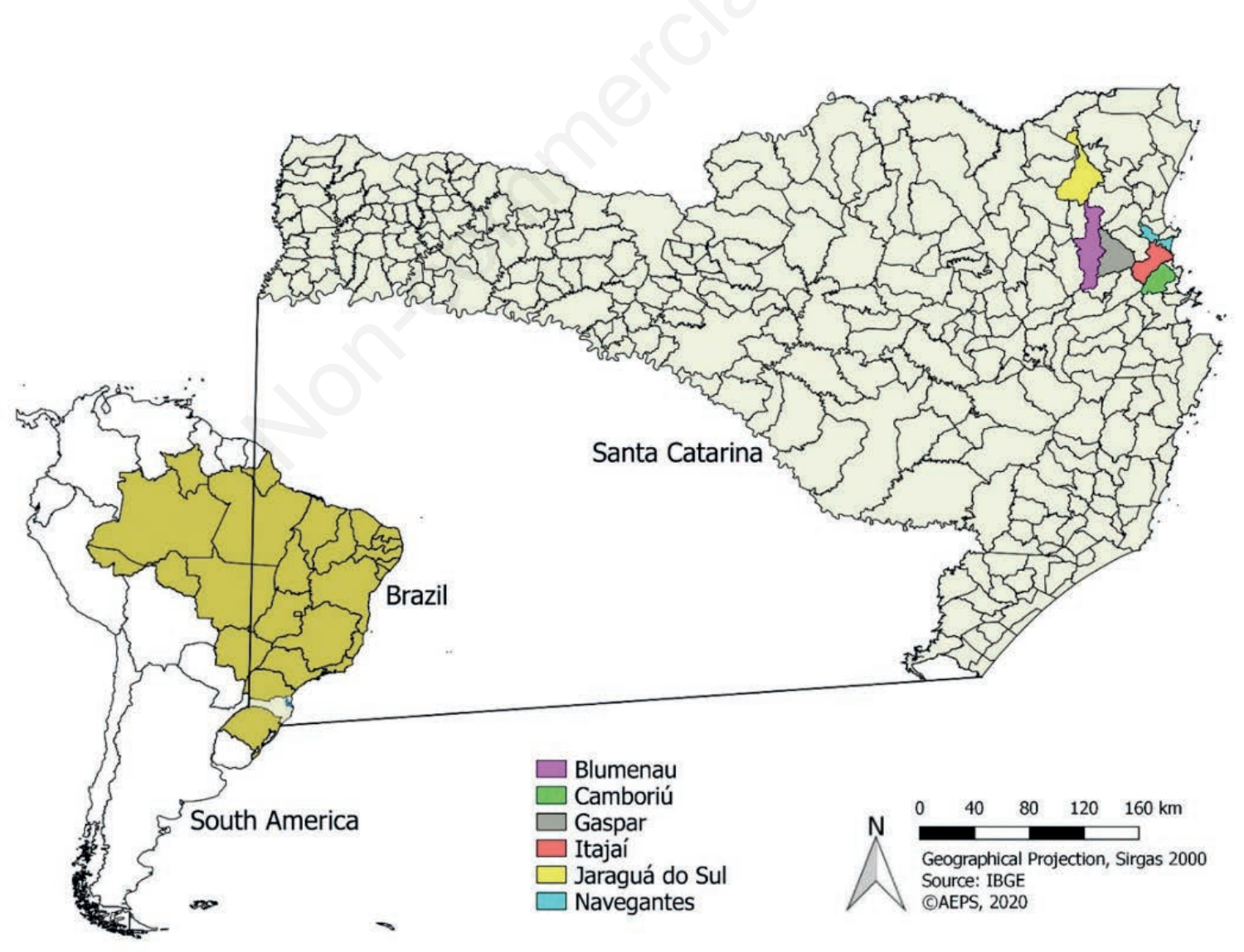

Figure 1. Location of the six study municipalities in Santa Catarina State, Brazil. 
storms, tornadoes and coastal erosion. The municipalities of SC with a historical risk of natural disasters were mapped to indicate areas characterized by potential occurrence of such events. Among the municipalities selected for this study, Camboriú, Navegantes, Itajaí, Gaspar and Jaraguá do Sul were mapped in 2011 and 2012 by the Geological Survey of Brazil, also known as Mineral Resources Research Company (Companhia de Pesquisa de Recursos Minerais, CPRM), while the Municipal Risk Reduction Plan (Plano Municipal de Reducão de Risco, PMRR) mapped the municipality of Blumenau in 2013. These maps were obtained from the National Center for Monitoring and Alerts for Natural Disasters (Cemaden). Information about the rivers that cross the studied municipalities was obtained from the National Water Agency (Agência Nacional de Águas, ANA, 2020). (http://www3.ana.gov.br/)

\section{Socioeconomic ranking}

Human development can be described by two development indices: The Human Development Index (HDI) and the methodological adjustment to the global HDI called MDHI but it is not possible to make a comparison between the MHDI of a municipality and the HDI of a country. In the 2010 Census, SC had an HDI of 0.774 , giving the state a third-place rank in Brazil. The six municipalities selected for this study had values ranging from high ( 0.700 to 0.799$)$ to very high ( 0.800 to 1$)$. Blumenau was the most developed among them with an MHDI of 0.806 (25th place in Brazil), followed by Jaraguá do Sul at 0.803 (34th place in Brazil), Itajaí at 0.795 (56th place in Brazil), Gaspar at 0.765 (289th place in Brazil), Navegantes at 0.736 (876th place in Brazil) and Camboriú at 0.726 (1,133th place in Brazil) (IBGE, 2010).

\section{Resident population information and case information}

The DATASUS website was used to obtain the population of all municipalities in the state of SC from 2000 to 2015, including the population of the six municipalities included in the study, from the census conducted in 2010 .

Information on confirmed cases of leptospirosis in the six selected municipalities was provided by the Health Authority of SC for the period 2000 to 2016 using the Notification Disease Information System (Sistema de Informação de Agravos de Notificação, SINAN) based on Leptospirosis Investigation Forms. This information included, but was not limited to, age, sex and home address of each patient. Six datasets were analyzed, one from each selected municipality. The numbers of cases for the period 2000 to 2016 analyzed in each municipality were as follows: 513 in Blumenau, 50 in Camboriú, 186 in Gaspar, 293 in Itajaí, 507 in Jaraguá do Sul and 59 in Navegantes.

At least one of the following criteria had to be met to confirm a case of leptospirosis: clinical-laboratory or clinical-epidemiological. The former criterion was based on one or more positive test results, while the latter took into account whether a suspected patient with no tests performed, or initially negative test results, had a suggestive epidemiological history within 30 days prior to the onset of symptoms, such as exposure to floods, sewage, garbage, risky occupational activities and presence in a high-risk leptospirosis area $(\mathrm{MoH}, 2017)$.

\section{Leptospirosis incidence}

For each municipality, annual disease incidence rates were calculated per 100,000 inhabitants, standardized by gender and age group. The direct method was used, taking the population of SC state in 2010 as standard. Standardization aims to avoid the influence of variations by gender and age group in the population, between municipalities.

\section{Geocoding process}

Addresses to be geocoded were standardized and the spelling of street names, especially those containing foreign words which are very common in the municipalities studied, was verified. Geocoding was performed based on the EasyMapMaker website (http://www.easymapmaker.com), which searches for address location in Google Maps and provides the corresponding geographic coordinates (latitude and longitude).

To assess the accuracy of this procedure, approximately $10 \%$ of the addresses in each municipality were selected at random for a total of 170 addresses. Each address was entered into Google Maps and the coordinates provided by EasyMapMaker were verified. The overall proportion of correct entries was calculated, and the geocoding was considered adequate if this ratio was $\geq 95 \%$. Later, the incorrectly located addresses were fixed. After this procedure, the cases were spatialized with QGIS (https://github.com/ qgis/QGIS).

\section{Scan statistics}

To geographically locate clusters of leptospirosis incidence in space and time in the six selected municipalities, purely spatial, purely temporal, spatiotemporal and spatial variation of temporal trends statistics were applied using SaTScan software, version 9.6 (https://www.satscan.org/). Only high incidence rates of the disease were detected, as that was the information relevant to the study. Because leptospirosis data were characterized as case counts, a discrete Poisson model was applied using the case and population counts of each of the six municipalities by census tract and their respective geographic coordinates (Kulldorff, 1997; 2015). The census tracts and the year of onset of symptoms were considered aggregation units. In performing the scan statistics, the following information was provided to SaTScan: i) Year of occurrence, Census tract code, sex and age range of leptospirosis cases (covariates used for adjustment); ii) Population data stratified by sex and age group of each census tract obtained from the 2010 census; and iii) Geographic coordinates of the centroids of the Census tracts.

The following yearly age groups were considered: 0-9, 10-19, $20-59$ and $\geq 60$. Studies show that leptospirosis predominantly affects the most economically active population, which is composed of those between 15 and 59 years old (Paploski, 2013; Gonçalves et al., 2016; Lara et al., 2019). The Monte Carlo test was performed with 999 replications to ensure robust estimates. To define the maximum size of the spatial cluster in relation to the population, the Gini coefficient, available in the purely spatial scan statistic, was used to determine which non-overlapping spatial clusters should be reported. The optimal Gini coefficient (i.e. the highest possible value with $\mathrm{P}<0.05$ ) suggests which proportion of the population should be used in the cluster composition (Han et al., 2016). 


\section{Results}

\section{Incidence}

Table 1 presents the incidence rates of leptospirosis for male, female and both (male and female) by age group in SC during the study period. The disease was more prevalent in men and in ages 15-69 years. Figure 2 shows the standardized incidence rate of leptospirosis over the study period in the six selected municipalities. Throughout most of the period, the Gaspar and Jaraguá do Sul municipalities had the highest incidence rates. There was a peak of disease occurrence in 2008, when the incidence ranged from 39 to 78 per 100,000 inhabitants across the municipalities and a second, somewhat lower peak in 2011.

\section{Geocoding}

In the standardization stage, two cases were excluded due to lack of a complete address. In the first standardized data entry procedure, four cases were excluded because the addresses were not found. In the second data entry procedure, 42 more cases were excluded because the addresses were not located within their respective municipalities. For 273 cases, the addresses were incomplete, and geocoding was performed with the name of the street or neighbourhood only. In 25 cases, the address contained poorly defined names such as "road", which made them impossible to locate, and geocoding was performed with the name of the neighbourhood only. As a result, 1,608 (97.1\%) out of the 1,656 cases of leptospirosis in the six selected municipalities were geocoded.

In the verification stage, the Camboriú, Gaspar and Navegantes municipalities did not have any errors in addresses location (100\% correct). Blumenau and Itajaí had one error each
(98\% and 97\% correct, respectively). In Jaraguá do Sul, six errors were found, probably due to the greater number of addresses with incomplete and poorly filled names in relation to the other municipalities (88\% correct). In total, $95.3 \%$ of the sampled addresses were considered correctly geocoded, a proportion considered adequate. Most cases of geocoded leptospirosis were located within the areas designated as urban by the 2010 Census by the IBGE in each of the six municipalities. The distribution of these cases by municipality can be seen in Figure 3.

\section{Identification of leptospirosis clusters}

The purely temporal scan statistic detected significant clusters in all municipalities. Figure 4 shows a scheme of this result, indicating the years in which significant, high-incidence leptospirosis clusters were detected. The purely spatial scan statistic, on the other hand, did not detect significant clusters in any of the six

Table 1. Specific incidence rate of leptospirosis stratified by sex and age group. Santa Catarina State, Brazil 2001-2015.

\begin{tabular}{lccc} 
Age group (years) & Male & Female & Total \\
0 to 4 & 1.2 & 0.6 & 0.9 \\
5 to 9 & 1.9 & 0.9 & 1.4 \\
\hline 10 to 14 & 7.7 & 1.9 & 4.8 \\
15 to 19 & 12.9 & 1.8 & 7.5 \\
\hline 20 to 39 & 14.6 & 2.9 & 8.8 \\
40 to 59 & 15.7 & 3.3 & 9.5 \\
\hline 60 to 69 & 10.3 & 2.3 & 6.1 \\
70 to 79 & 4.7 & 1.1 & 2.6 \\
\hline 80 and more & 1.5 & 0.6 & 0.9 \\
\hline
\end{tabular}

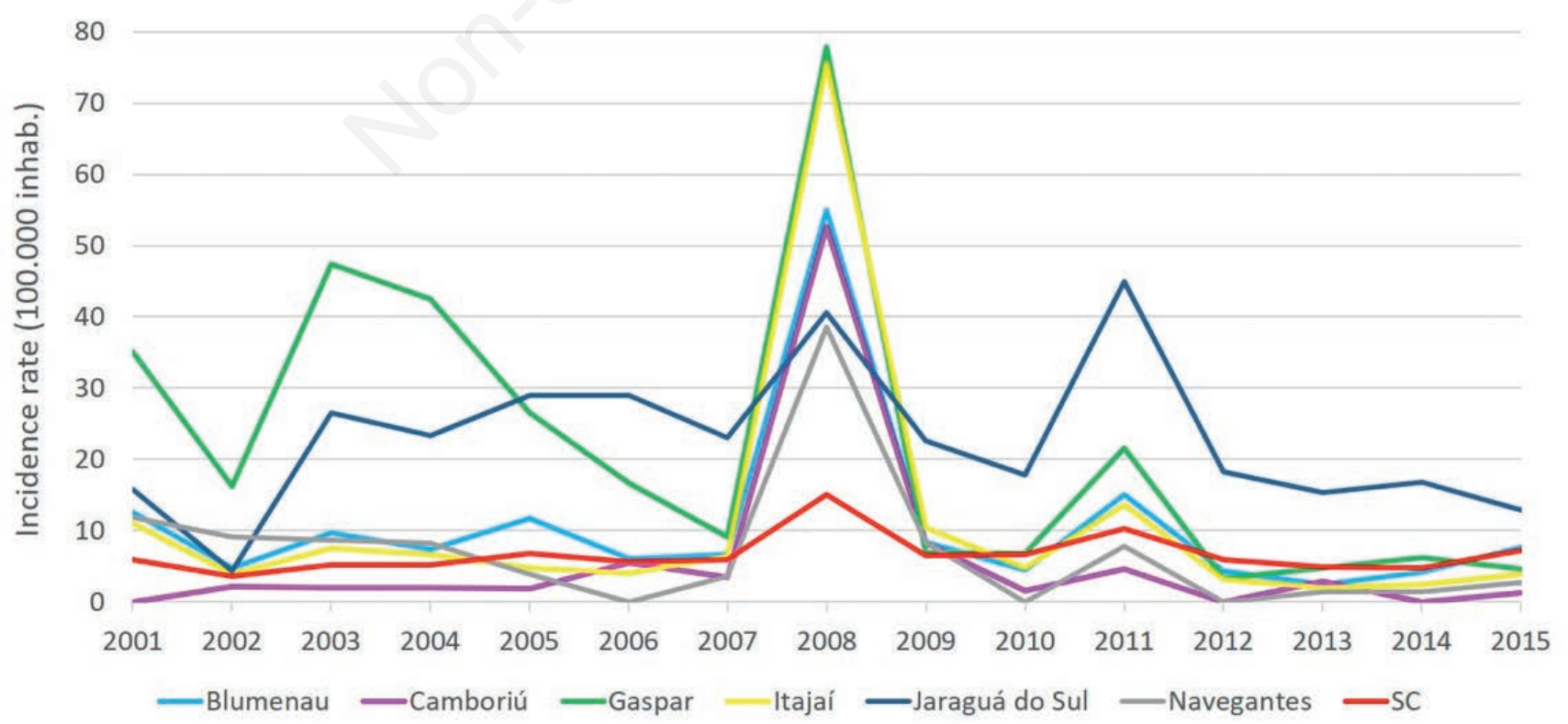

Figure 2. Standardized incidence rate over time by municipality and state in Santa CatarinaState, Brazil in the period 2001-2015. 
municipalities, and it was not possible to use the Gini coefficient to define the maximum size of spatial clusters in relation to the population. Therefore, in the other scanning statistics performed (spatiotemporal and spatial variation of temporal trends), the standard percentage of a maximum of $50 \%$ of the population for all municipalities was adopted with time expressed in years and no spatial and temporal overlapping of clusters (Kulldorff, 1997; 2015). As the spatial variation sweep statistic of the temporal trends did not detect significant clusters either, there was no evidence of an increasing trend in incidence over the years in any of the municipalities. The spatiotemporal scan, however, detected significant clusters in all municipalities in 2008. In Jaraguá do Sul, there were clusters in the periods 2008-2009, 2008-2011 and particularly in 2011, when the municipality received above normal amounts of rainfall. This municipality had slightly different clusters, as they were not all located in urban regions, where most

\section{- Leptospirosis cases \\ $\square$ Urban area \\ $\square$ Blumenau \\ $\square$ Camboriú \\ $\square$ Gaspar \\ $\square$ Itajai \\ Jaraguá do Sul \\ Navegantes}

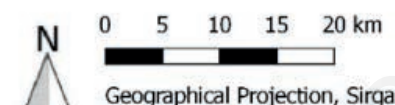

Geographical Projection, Sirgas 2000

Source: IBGE e SINAN

(C)AEPS, 2019

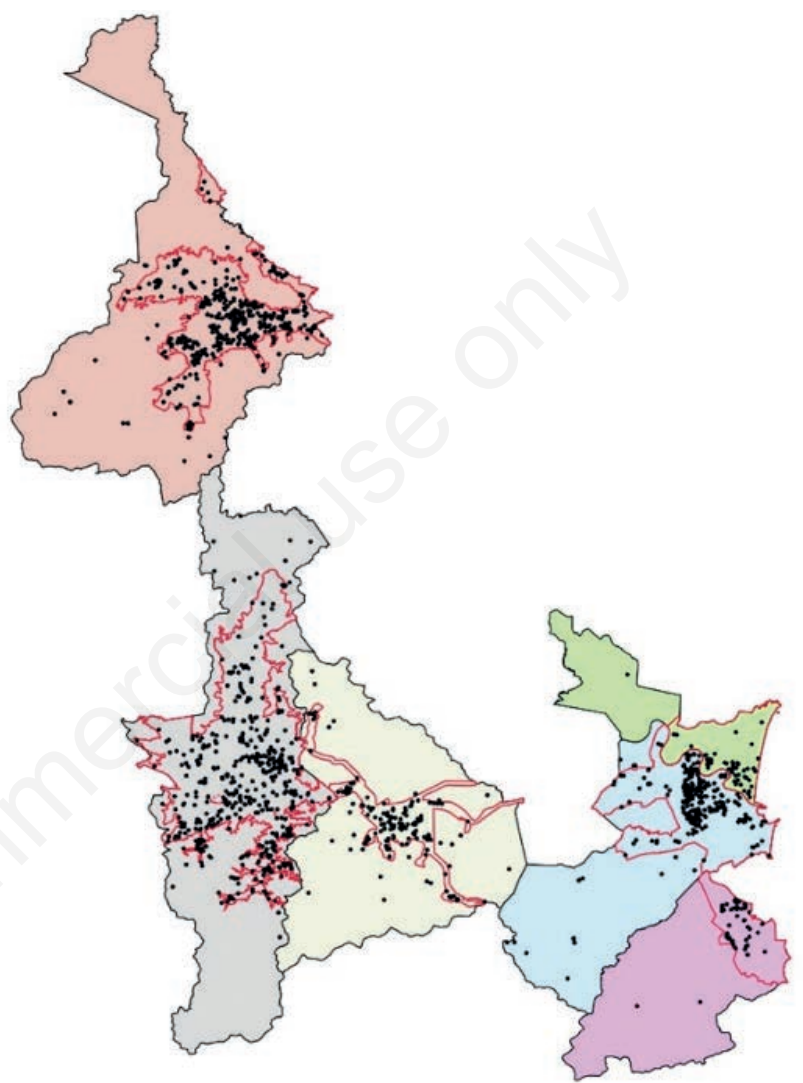

Figure 3. Leptospirosis cases geocoded by residential address in the six municipalities studied between 2000 and 2016 in Santa Catarina State, Brazil.

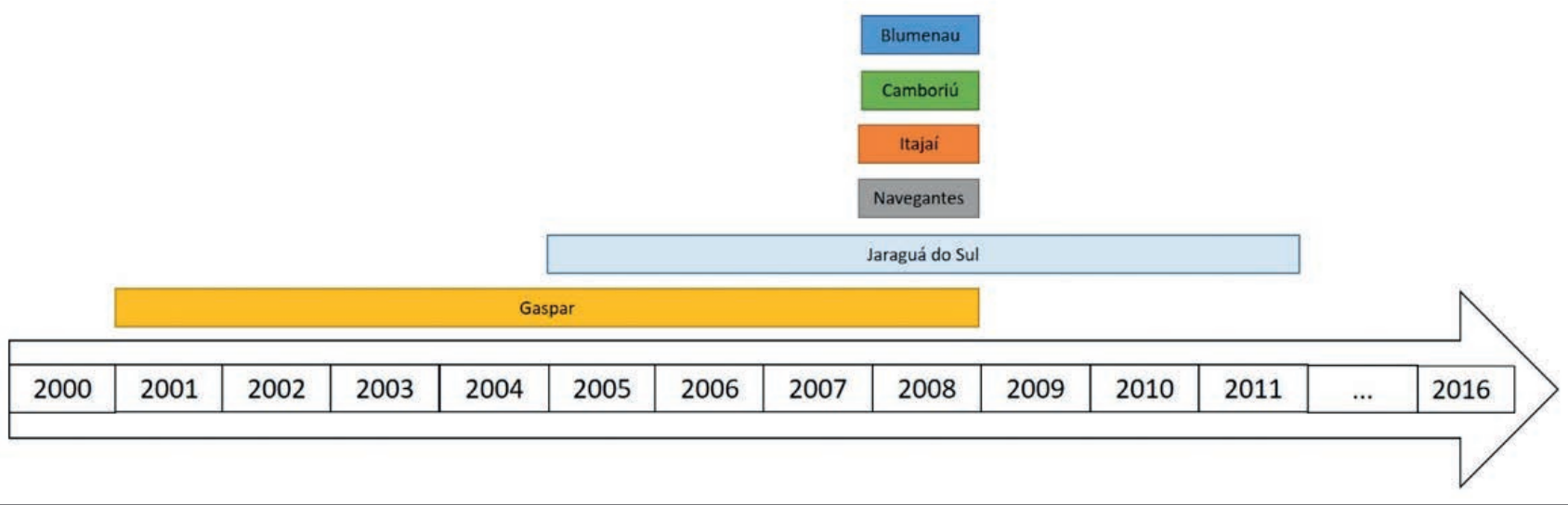

Figure 4. Purely temporal clusters detected in the six municipalities studied between 2000 and 2016 in Santa Catarina State, Brazil. 
cases of leptospirosis usually occur. A few cases of leptospirosis spread over a large area with a small population because of the rural situation. All these clusters coincided with the purely temporal clusters.

Figures 4 and 5 show the geographical locations and the periods in which the clusters occurred, as well as their relative risk valuations. In the scanning analysis, the relative risk of a spatial cluster represents how much more common the disease under study is in the region and time period detected compared to any other region throughout the study period, even in the region under study during any other period of time.

In Blumenau, two clusters were identified in 2008: the first in 229 Census tracts, covering the entire northern half of the municipality and with a relative risk of 7.5, and the second in 184 Census tracts with a relative risk of 6.6 (Figure 5-A1). This means that the risk of contracting leptospirosis in 2008 was 6.5 times higher in the

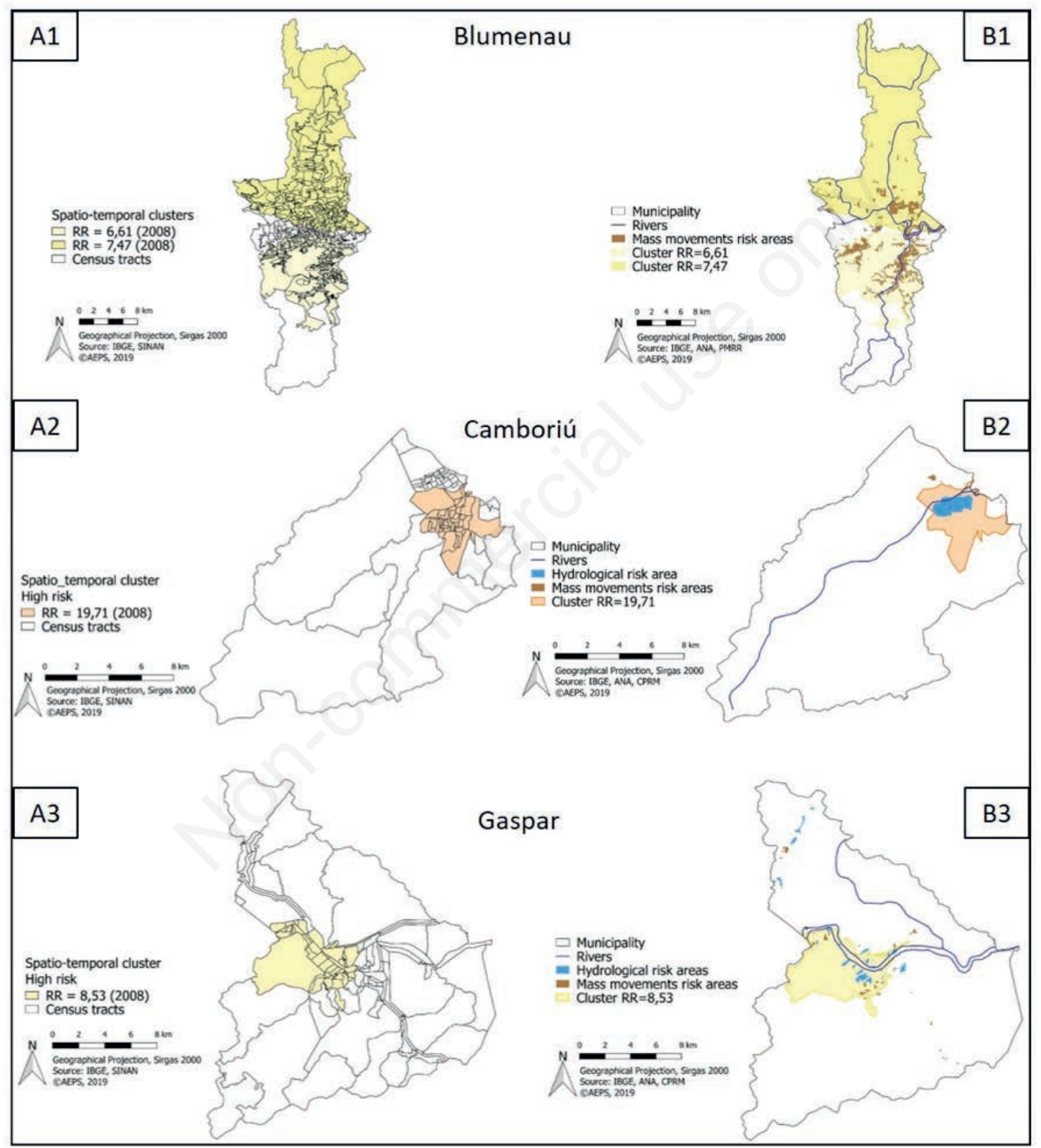

\section{A) spatiotemporal clusters and B) areas at risk for natural disasters; 1) Blumenau; 2) Camboriú; 3) Gaspar.}

Figure 5. Spatiotemporal clusters and areas at risk of natural disasters in Blumenau, Camboriú and Gaspar between 2000 and 2016 in Santa Catarina State, Brazil. 
first space-time cluster and 5.6 times higher in the second one than in areas outside it. These clusters covered approximately $83 \%$ of the municipality's population including some rural sectors, where few cases are usually recorded and the population is small.

In 2008, several clusters were identified, one each in the following three municipalities. In Camboriú, one cluster was located in the middle of its urban area, which is composed of 39 Census tracts, covering $47 \%$ of the population, with a relative risk of 19.7
(Figure 5-A2); in Gaspar, a significant cluster was located in the Midwest region of the municipality, including 44 Census tracts, representing $41 \%$ of the population, with a relative risk of 8.5 (Figure 5-A3). Only one Census tract of the cluster was rural; the others urban; and in Itajaí another significant cluster was located in the western part of the municipality, including 140 tracts, corresponding to $52 \%$ of the population with a relative risk of 16.1 . This cluster comprised five rural tracts; the others were urban (Figure 6-

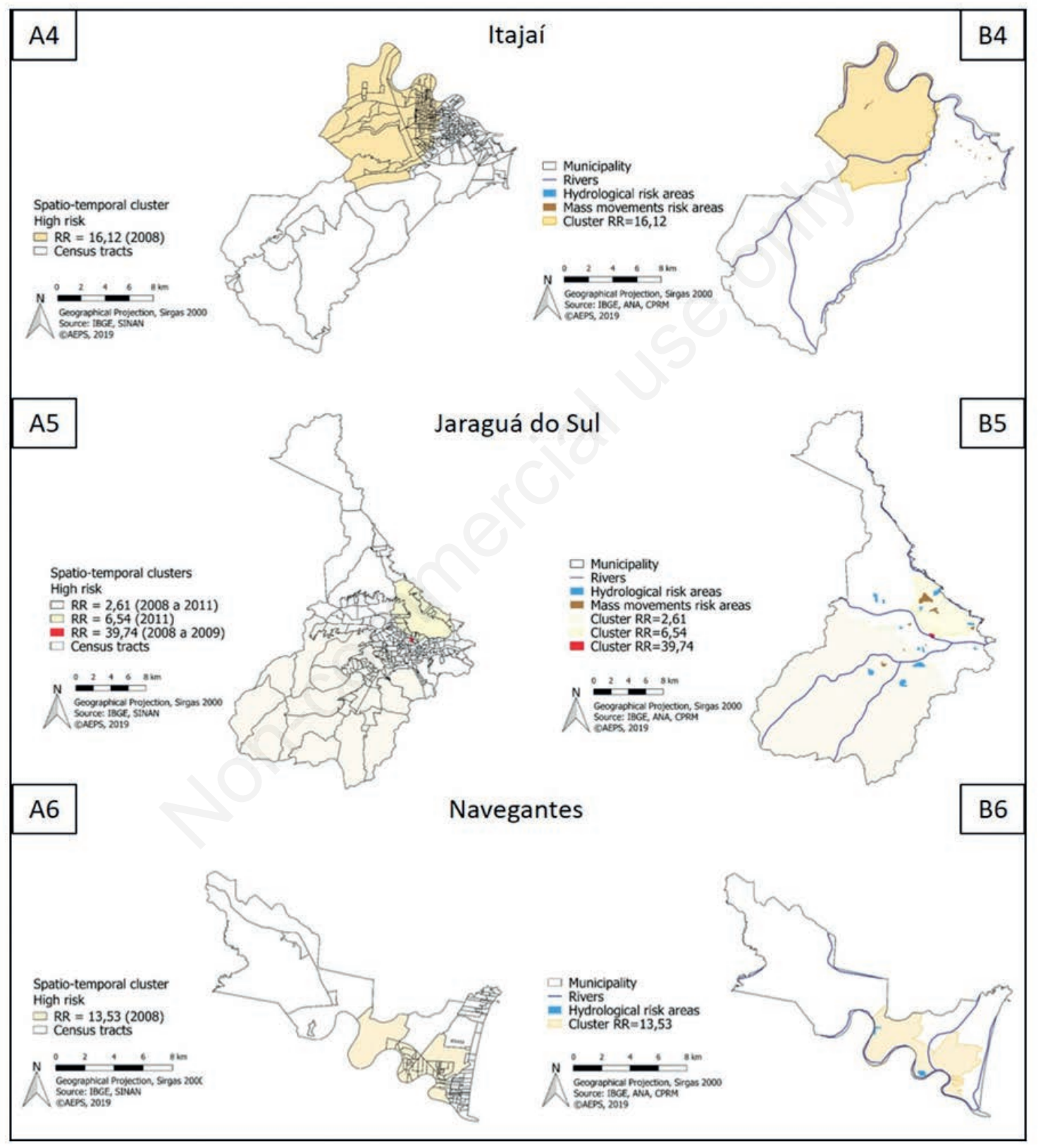

\section{A) spatiotemporal clusters and B) areas at risk for natural disasters; 4) Itajaí; 5) Jaraguá do Sul; 6) Navegantes.}

Figure 6. Spatiotemporal clusters and areas at risk of natural disasters in Itajaí, Jaraguá do Sul and Navegantes between 2000 and 2016 in Santa Catarina State, Brazil. 
A4). In Jaraguá do Sul, three clusters were identified. The largest included 56 Census tracts and had a relative risk of 2.6 for the period from 2008 to 2011; another with 16 tracts had a relative risk of 6.5 for the year; while the third and smallest contained only one tract located in the central region of the municipality, with a relative risk of 39.7 for the period 2008 to 2009 . Together, these three clusters contained $36 \%$ of the population and $19 \%$ of the rural Census tracts, most of which located in the South and part of the largest cluster (Figure 6-A5). In total, Jaraguá do Sul has 215 Census tracts. Like Camboriú, Gaspar and Itajaí, Navegantes had a significant cluster in 2008, including 35 Census tracts, all of which were urban (covering $46 \%$ of the population), with a relative risk of 13.5 (Figure 6-A6).

\section{Situation with respect to natural disasters}

Each of the six municipalities in the study was mapped and assessed for the risk of natural disasters, which were classified as either purely hydrological events or mass movement, landslides being the most common among other movements. The maps are shown in Figures 5 and 6 (B1 to B6). The areas at risk both for hydrological events and landslides natural disasters presented in the maps can be seen to largely coincide with the areas where clusters of high leptospirosis rates were detected in the spatiotemporal analysis. They are predominantly urban areas that contain the great majority of the populations of these municipalities and are crisscrossed by rivers that can overflow during heavy rainfall.

In 2008, the rainfall reached volumes never before recorded, especially in regions of Greater Florianópolis, Itajaí Valley and Northern Coastal, triggering flashfloods with high water levels leading to land- and mudslides in several municipalities in the north-eastern part of the state (Silva Dias, 2009; Zucco et al., 2010; Xavier et al., 2014a; 2014b; Londe et al., 2015). According to the official civil defence document Damage Assessment (Avaliação de Danos, AVADANS) that recorded the disaster, the municipality of Blumenau received $112 \mathrm{~mm}$ of rainfall in six hours, $500 \mathrm{~mm}$ in two days and reaching $588 \mathrm{~mm}$ at the end of five consecutive days without adequate water outflow conditions. This led to partial flooding of the central area and several neighbourhoods in addition to slips and landslides of medium and large proportions. Camboriú received $262 \mathrm{~mm}$ of rain from 21 to 23 November resulting a total measure for the month of $466 \mathrm{~mm}$, well above the average for the period. There were also increased river levels due to flashfloods leading to general flooding with landslides. In Gaspar, heavy rains between 21 and 24 November amounted to $514 \mathrm{~mm}$ causing sudden floods and landslides (S2ID, 2018).

According to AVADANS, Itajaí suffered the impacts of the high volume of rain that fell in the middle and lower portions of valley containing the Itajaí-Açú River. Out of $472 \mathrm{~mm}$ of rain recorded in four days, $190 \mathrm{~mm}$ came in just one day. This caused overflow of the rivers Itajaí-Açú and Itajaí Mirim. In Jaraguá do Sul, above normal rainfall was recorded throughout the month of November $(1,100 \mathrm{~mm})$, with particularly great intensities on days 21,22 and 23 of the month $(600 \mathrm{~mm})$. In Navegantes, the amount of rainfall reached $325 \mathrm{~mm}$ in the period from 21 to 25 November, and the average for the month was approximately $160 \mathrm{~mm}$. The heavy rains caused flashfloods and the overflow of the Itajaí-Açú River and some of the municipality streams. Some of these municipalities also reported damage to the water distribution network, water and sewage treatment as well as waste collection and treatment in the post-disaster period (S2ID, 2018), all favourable conditions for the transmission of leptospirosis.
In 2011, Jaraguá do Sul was greatly affected by heavy rains (Silva, 2014), particularly in the southern part of the region.

\section{Discussion}

Historically, the highest incidence of leptospirosis was recorded in 2008 in five of the six municipalities; Jaraguá do Sul being the exception, which recorded the highest incidence in 2011, followed by 2008. Significant increases in incidence have been reported to occur in periods after flooding, both in 2008 and 2011 (Silva Dias 2009; Silva, 2014). The highest incidence of leptospirosis in SC occurred in men in the economically active age group confirming previous studies reporting higher incidence, hospitalization and mortality rates due to disease in economically active men (Souza et al., 2011; Gonçalves et al., 2016). Although there is no scientific evidence of any predisposition that may favour infection in men or this age group per se, exposure-related factors are believed to be connected to occupation in commonly flooded areas, which are likely sites of ongoing transmission of the disease. With regard to the spatialization of the cases, it was observed that they were concentrated in urban areas in all six municipalities. All municipalities detected purely temporal clusters. The municipalities of Camboriú, Gaspar, Itajaí and Navegantes each had a spatiotemporal cluster with a high incidence rate in 2008. Blumenau had two clusters in 2008, and Jaraguá do Sul had three clusters in 2008 and 2011. The periods in which these clusters occurred coincided with severe natural disasters, especially in 2008, when all the municipalities studied were affected. This explains why significant clusters were found in the purely temporal and spatiotemporal scan statistics, but not in the spatial scan statistics; as interaction between time (time of disaster occurrence) and space (natural disaster risk areas) was a determining factor for the formation of clusters. Thus, the population with the highest incidence of leptospirosis in the six municipalities studied lived in high-risk areas that experienced natural disasters in 2008 and 2011.

The spatial and spatial variation analyses of temporal trends did not detect significant clusters in the six municipalities. However, both the purely temporal and the spatiotemporal method detected clusters. In this case, the occurrence of high incidence rates of leptospirosis was not only associated with a specific location but also with a certain period of time (occurrence of natural disasters), since temporal clusters were detected in all municipalities. Therefore, this is an indication that the interaction between space and time was decisive for the detection of high rates of leptospirosis.

Most cases of spatialized leptospirosis and most detected clusters occurred in urban areas, which contain the majority of the inhabitants in the municipalities, especially economically disadvantaged population. In addition, urban areas often have inadequate sanitation and rubbish collection, which can cause infestations of infected rodents. Pelissari et al. (2011) observed that there is a difference with respect to the factors involved in the transmission of leptospirosis in urban and rural areas. In the former, epidemic outbreaks are preceded by increased rainfall that connect the disease to low socioeconomic levels as well as precarious environmental conditions, while the disease is more commonly associated with agricultural activities, such as rice planting and irrigation in the latter. This is echoed by the present study that mostly found cases of leptospirosis in urban areas and that the population with 
the highest incidence of leptospirosis resides in areas identified as being at high risk for natural disasters. In all the municipalities studied, the areas where the disease clusters were located either presented some risk of hydrological events or landslides, e.g., when bordered by rivers prone to overflow during heavy rainfall.

Most of the detected clusters occurred in 2008, when the largest natural disaster in SC occurred (Silva Dias, 2009), but Jaraguá do Sul had also clusters of cases in 2011, when the municipality was greatly affected by heavy rains (Silva, 2014). The different kind of clusters noted in Jaraguá do Sul were not all located in urban regions, where most cases of leptospirosis usually occur. This may have occurred because incidence rates were higher in the less populated areas, while there were a few cases of leptospirosis spread over a large area with a small population resulting in high rates, which may have favoured the detection of these Census tracts as part of the cluster.

Although leptospirosis has seasonal trends due to increased rainfall volume and intensity in summer, the epidemics in SC occurred mainly after major hydrological disasters (Santos et al., 2012), which did not necessarily occur during the summer. For example, the highest incidence in the study period was due to the event of November 2008. It is not always possible to predict natural disasters or their intensity, as this depends on the characteristics of the region and the meteorological event involved (Silva Dias, 2009; 2014). However, after the occurrence of a natural disaster, it is possible to apply surveillance measures to prevent leptospirosis epidemics, either by reducing individual and collective exposure after floods or by preventing natural disasters, which involve social and environmental aspects.

SaTScan has been used in Brazil and worldwide, leading to the discovery of important results in the area of public health. With the techniques of scanning statistics, it was possible to identify areas and periods of a higher incidence of the disease, enabling the characterization of epidemics and not just a random increase in the number of cases.

\section{Limitations}

The main limitation of the study was the use of secondary leptospirosis data. As a result, it was not possible to verify the quality of the information or complete the addresses with missing information in the SINAN records. However, all data were considered suitable for this study because they were obtained from public agencies. Another limitation was in relation to the processing time of SaTScan, which depends on the analysis unit chosen: the more disaggregated the data, that is, the smaller the unit of analysis, the longer the processing time. For discrete scanning statistics used in this study, the geographic locations where the data are observed were non-random and determined by the researcher. These locations may be the actual locations of observations, such as residences, or it may be a central location that represents a larger area, such as the geographical centroids of the Census tracts. Due to the irregular shapes of many Census tracts, the use of the centroid of the tracts as an aggregation unit must be recognized as another limitation: some cases may be closer to centroids of neighbouring tracts. Despite that, these limitations were considered not to invalidate the study.

\section{Conclusions}

The cluster detection approach used in the present study can also identify and map endemic risk areas and thus contribute to the prevention of leptospirosis. As the interaction between time (time of disaster occurrence) and space (natural disaster risk areas) is a determining factor in cluster formation, significant clusters coinciding with severe natural disasters were found in purely temporal and spatiotemporal scan statistics but not in purely spatial approaches.

\section{References}

ANA, 2020. [Agência Nacional de Águas e Saneamento Básico (ANA).] Available from: http://www3.ana.gov.br/. Accessed: April 20, 2019. [Website in Portuguese].

Bermudi PMM, Guirado MM, Rodas LAC, Dibo MR, Chiaravalloti Neto F, 2018. Spatio-temporal analysis of the occurrence of human visceral leishmaniasis in Araçatuba, State of São Paulo, Brazil. Rev Soc Bras Med Trop 51:452-60. doi:10.1590/0037-8682-0505-2017

Cardim MFM, Guirado MM, Dibo MR, Chiaravalloti Neto F, 2016. [Leishmaniose visceral no estado de São Paulo, Brasil: análise espacial e espaço-temporal.] Rev Saude Publica 50:111. [Article in Portuguese]. doi:10.1590/S1518-8787.2016050 005965

Coleman M, Coleman M, Mabuza AM, Kok G, Coetzee M, Durrheim DN, 2009. Using the SaTScan method to detect local malaria clusters for guiding malaria control programmes. Malar J 8:1-6. doi:10.1186/1475-2875-8-68

DATASUS, 2019. [Informações de Saúde (TABNET)]. Available from: http://datasus1.saude.gov.br/informacoes-de-saude/tabnet [Website in Portuguese]. Accessed: May 11, 2019.

Deshmukh P, Narang R, Jain J, Jain M, Pote K, et al., 2019. Leptospirosis in Wardha District, Central India - Analysis of hospital based surveillance data. Clin Epidemiol Glob Health 7:102-6.

Farinelli EC, Baquero OS, Stephan C, Chiaravalloti Neto F, 2018. Low socioeconomic condition and the risk of dengue fever: A direct relationship. Acta Trop 180:47-57. doi:10.1016/j.actatropica.2018.01.005

Freitas CM, Silva DRX, Sena ARM, Silva EL, Sales LBF, 2014. [Desastres naturais e saúde: uma análise da situação do Brasil.] Cien Saude Colet 19:3645-56. [Article in Portuguese]. doi:10.1590/1413-81232014199.00732014

Gonçalves NV, Araújo EM, Sousa Júnior AS, Pereira WMM, Miranda CSC, 2016. [Distribuição espaço-temporal da leptospirose e fatores de risco em Belém, Pará, Brasil.] Cien Saude Colet 21:3947-55. [Article in Portuguese]. doi:10.1590/1413-812320152112.07022016

Gutiérrez JD, Martínez-Veja RA, 2018. Spatiotemporal dynamics of human leptospirosis and its relationship with rainfall anomalies in Colombia. Trans R Soc Trop Med Hyg 112:1153. doi:10.1093/trstmh/try032

Han J, Zhu L, Kulldorff M, Hostovich S, Stinchcomb DG, et al., 2016. Using Gini coefficient to determining optimal cluster reporting sizes for spatial scan statistics. Int J Health Geogr 15:1-11. doi:10.1186/s12942-016-0056-6

IBGE, 2018. [Santa Catarina.] Available from: https://cidades.ibge. 
gov.br/brasil/sc/panorama. Accessed: June 09, 2019. [Website in Portuguese].

IBGE, 2010. [Conheça cidades e estados do Brasil.] Available from: https://cidades.ibge.gov.br/. Accessed: June 09, 2019. [Website in Portuguese].

Kugeler K J, Farley GM, Forrester JD, Mead PS, 2015. Geographic Distribution and Expansion of Human Lyme Disease, United States. Emerg Infect Dis 21:1455-7. doi:10.3201/eid2108.141878

Kulldorff MA, 1997. A spatial scan statistic. Communications in Statistics - Theory and Methods 26:1481-96. doi:10.1080/036 10929708831995

Kulldorff MA, 2015. Information Management Services, Inc. SaTScanTM User Guide. SaTScanTM v. 9.4: Software for the spatial and space-time scan statistics. Boston (MA): Harvard University. Available from: http://www.satscan.org/ techdoc.html. Accessed: January 02, 2017.

Lara JM, Zuben AV, Costa JV, Donalisio MR, Francisco PMSB, 2019. [Leptospirose no município de Campinas, São Paulo, Brasil: 2007 a 2014.] Rev Bras Epidemiol 22:1-13. [Article in Portuguese]. doi:10.1590/1980-549720190016

Londe LR, Marchezini V, Conceição RS, Bortoletto KC, Silva AEP, et al., 2015. [Impactos de desastres socioambientais em saúde pública: estudos dos casos dos Estados de Santa Catarina em 2008 e Pernambuco em 2010.] Rev Bras Estud Popul 32:537-62. [Article in Portuguese]. doi:10.1590/S01023098201500000031

Melchior LAK, Chiaravalloti Neto F, 2016. Spatial and spatio-temporal analysis of malaria in the state of Acre, western Amazon, Brazil. Geospat Health 11:233-9. doi:10.4081/gh.2016.443

Ministry of Health, Brazil (MoH), 2017. Secretaria de Vigilância em Saúde. Coordenação-Geral de Desenvolvimento da Epidemiologia em Serviços. [Guia de Vigilância em Saúde. 2. ed. Brasília: Ministério da Saúde.] Available from: https://www.saude.pr.gov.br/sites/default/arquivos_restritos/fil es/documento/2020-04/volume-unico-2017.pdf Accessed: January 30, 2019. [Article in Portuguese].

Ministry of Health, Brazil (MoH), 2010. Secretaria de Vigilância em Saúde. Departamento de Vigilância Epidemiológica. [Doenças infecciosas e parasitárias: guia de bolso. 8. ed. rev.] Brasília: Ministério da Saúde. Available from: https://bvsms. saude.gov.br/bvs/publicacoes/doencas_infecciosas_parasitaria_guia_bolso.pdf Accessed: January 30,2019 . [Article in Portuguese].

OPAS, 2014. [Desastres Naturais e Saúde no Brasil. Série Desenvolvimento Sustentável e Saúde, 2.] Brasília, Fundação Oswaldo Cruz -Ministério da Saúde. [Article in Portuguese]. Available from: https://www.paho.org/bra/images/stories/ GCC/desastresesaudebrasil_2edicao.pdf

Paploski IAD, 2013. [História natural da leptospirose urbana: influência do sexo e da idade no risco de infecção, progressão clínica da doença e óbito.] Fundação Oswaldo Cruz, Salvador, Brazil. [Article in Portuguese]. Available from: https://www.arca.fiocruz.br/bitstream/icict/7175/1/Igor\%20Pa ploski\%20Historia\%20natural...2013.pdf

Pelissari DM, Maia-Elkhoury ANS, Arsky MLNS, Nunes ML, 2011. [Revisão sistemática dos fatores associados à leptospirose no Brasil, 2000-2009.] Epidemiol Serv Saude 20:565-74. [Article in Portuguese]. doi:10.5123/S167949742011000400016

Pellini ACG, Cavalin RF, Francisco MA, Chiaravalloti Neto F,
Zanetta DMT, 2017. [A trajetória da epidemia de aids nas mulheres residentes no município de São Paulo, de 1983 a 2012.] Hygeia 13:42-57. [Article in Portuguese]. doi:10.14393/ Hygeia132604

Pinto PFPS, Chiaravalloti Neto F, Ribeiro MCSA, 2018. Tuberculosis among South American immigrants in São Paulo municipality: an analysis in space and time. Int J Tuberc Lung Dis 22:80-5. doi:10.5588/ijtld.17.0320

Romero-Vivas CM, Falconar AK, 2016. [Leptospira spp. y leptospirosis humana.] Salud Uninorte 32:123-43. [Article in Portuguese]. doi:10.14482/sun.32.1.8479

Sistema Integrado de Informações sobre Desastres (S2ID), 2018.

[Arquivo Digital.] Available from: https://s2id.mdr.gov.br/ Accessed: April 15, 2018. [Website in Portuguese].

Santos LBL, Assis MC, Silva AEP, Angelis CF, 2012. [Sobre risco, ameaça e vulnerabilidade à Leptospirose em situações pósalagamentos, inundações e enxurradas: reconstruindo o episódio do Vale do Itajaí (2008-2009).] In: Congresso Brasileiro sobre Desastres Naturais - 14-17 de maio de 2012 - Rio Claro, SP. [Article in Portuguese]. Available from: https://www.researchgate.net/publication/230855750_Sobre_r isco_ameaca_e_vulnerabilidade_a_Leptospirose_em_situacoes_pos-alagamentos_inundacoes_e_enxurradas_reconstruindo_o_episodio_do_Vale_do_Itajai_2008-2009

Silva FA, 2014. [Percepção dos riscos e desastres ambientais dos anos de 2008 e 2011 em Jaraguá do Sul, SC.] Available from: https://repositorio.ufms.br:8443/jspui/handle/123456789/2013 Accessed: March 30, 2019. [Website in Portuguese].

Silva Dias MAF, 2014. [Eventos climáticos extremos.] Revista USP 103:33-40. [Article in Portuguese]. doi:10.11606/issn. 2316-9036.v0i103p33-40

Silva Dias MAF (Ed.), 2009. [As chuvas de novembro de 2008 em Santa Catarina: um estudo de caso visando à melhoria do monitoramento e da previsão de eventos extremos: nota técnica INPE-INMET-EPAGRI.] São José dos Campos. 67 pp. [Book in Portuguese].

Souza VMM, Arsky MLNS, Castro APB, Araújo WN, 2011. [Anos potenciais de vida perdidos e custos hospitalares da leptospirose no Brasil.] Rev Saude Publica 45:1001-8. [Article in Portuguese]. doi:10.1590/S0034-89102011005000070

Sulistyawati S, Nirmalawati T, Mardenta RN, 2016. Spatial analysis of leptospirosis disease in Bantul Regency Yogyakarta. KEMAS 12:111-9. Available from: https://journal.unnes. ac.id/nju/index.php/kemas/article/view/4615

Sumanta H, Wibawa T, Hadisusanto S, Nuryati A, Kusnanto H, 2015. Spatial Analysis of Leptospira in Rats, Water and Soil in Bantul District Yogyakarta Indonesia. Open J Epidemiol 5:2231. doi:10.4236/ojepi.2015.51004

Traxler RM, Callinan LS, Holman RC, Steiner C, Guerra MA, 2014. Leptospirosis-Associated Hospitalizations, United States, 1998-2009. Emerg Infect Dis 20:1273-9. doi:10.3201/ eid2008.130450

WHO, Leptospirosis. 2019. Available from: https://www.who. int/topics/leptospirosis/en/. Accessed: May 20, 2019.

WHO, 2010. Leptospirosis Burden Epidemiology Reference Group (LERG). Available from: https://www.who.int/ zoonoses/diseases/lerg/en/. Accessed: May 20, 2019.

WHO, 2009. Estimating the global burden of human Leptospirosis. Available from: https://www.who.int/zoonoses/diseases/ Lerg_brochure.pdf?ua=1. Accessed: May 20, 2019.

Xavier DR, Barcellos C, Barros HS, Magalhães MAFM, Matos 
VP, Pedroso MM, 2014a. [Organização, disponibilização e possibilidades de análise de dados sobre desastres de origem climática e seus impactos sobre a saúde no Brasil.] Cien Saude Colet 19:3657-68. [Article in Portuguese]. doi:10.1590/141381232014199.00992014

Xavier DR, Barcellos C, Freitas CM, 2014b. [Eventos climáticos extremos e consequências sobre a saúde: o desastre de 2008 em Santa Catarina segundo diferentes fontes de informação.]
Ambiente \& Sociedade 17:273-94. [Artcile in Portuguese]. doi:10.1590/1809-4422ASOC1119V1742014.

Zucco FD, Magalhães MRA, Moretti SLA, 2010. [Gestão de Riscos e Desastres Naturais no Turismo: um estudo do município de Blumenau/SC.] Rev Turismo Em Análise 21:594-620. [Article in Portuguese]. doi:10.11606/issn.1984-4867.v21i3 p594-620 